DOI: 10.21892/978-958-5547-65-0.4

\title{
4. Agroforestry as an environmental innovation tool for agriculture in regions particularly affected by climate change
}

Emiliano Farinella ${ }^{1}$

Alice Costa ${ }^{2}$

\section{Introduction}

Climate change and increasing population are inducing the entire society to face the problem of food security (Intergovernmental Panel on Climate Change, 2014; Wheeler \& Von Braun, 2013). The impact of climate change on agriculture is already evident and it will become more serious during the next decades (Lobell, Schlenker, \& Costa-Roberts, 2011; Campbell et al., 2016), damaging especially the poorest people in the world (FAO, 2011; IFAD, 2011). Therefore, as an attempt to adaptation, people affected by the impact of climate change will intensify migration to the less concerned regions (Reuveny, 2007), making the problem even more global.

However, in the areas where climate change will implicate drought, extreme events and loss of habitants (IPCC Fifth Assessment Report, 2014), a different kind of adaptation can be implemented through the services provided by the ecosystem. Agroforestry, as a combination of agriculture and forestry can create integrated and suitable land-use systems (USDA National Agroforestry Center, 2015), and be a valid response to climate change including both adaptation and mitigation (Schoeneberger et al., 2012; Verchot et al., 2007).

Forests have one of the highest economic value among the terrestrial ecosystems (De Groot et al., 2012) because of the numerous local, regional and global services and goods that originated from them (Pearce \& David,

1 Bachelor of Economics, Università di Palermo, Italy. Master's degree in Engineering, Università di Palermo, Italy. Master in Project Management, Politecnico di Milano, Italy.

2 Bachelor's Degree in Natural Sciences, Università di Padova, Italy. Master's Degree in Natural Sciences, Università di Padova, Italy. 
2001; Nasi, Wunder, \& Campos, 2002). Furthermore, during climate change forests can make a big difference to the population in the form of mitigation and adaptation to the impacts (Locatelli, Kanninen, Brockhaus, Colfer, Murdiyarso, \& Santoso, 2008).

In particular, the ability of carbon sequestration performs the function of mitigation of $\mathrm{CO}_{2}$ emissions and storage of carbon in woody biomass and soil (Lal, 2005). Moreover, forests can intensify and improve the water cycle through evapotranspiration, moisture trapping and water depuration (Ellison, Futter, \& Bishop, 2012), and consequently enhance agriculture even in semi-arid areas. Finally, the forest ecosystem creates a microclimate as well as a physical barrier that mitigates the climate and protects the environment from extreme events (Schoeneberger et al., 2012).

Further reasons to adopt agroforestry are given by the increase of ecosystem resilience with the increase of biodiversity (Olson et al., 2000) and the improvement of soil quality and the balancing of nutrient cycles by the positive interaction and synergies between plants (Schwab, Shickhoff, \& Fischer, 2015).

In conclusion, we will demonstrate how agroforestry can represent an effective tool for agriculture in regions particularly affected by climate change and how the agroforest ecosystem can respond to impacts and serve as adaptation in different climatic and geographic areas.

\section{Agroecosystem Threats}

During the last decades agroecosystems have been seriously endangered by land degradation and climate change, causing severe losses to crops and a strong decrease of productivity. The most damaged areas are set mainly in developing countries, where the impact of climate change is stronger, the soil is heavily impoverished by deforestation and grazing, and lack of technology does not enable people to cultivate efficiently. Nevertheless, developed countries are also facing problems such as loss of habitat and biodiversity, eutrophication of ecosystems, salinization, air pollution, concentration of pesticides in groundwater and extreme weather events due to climate change. 


\subsection{Climate Change Impacts}

The greenhouse effect is a mechanism that enables the atmosphere to absorb the outgoing long-wave thermal radiation and reradiate back the energy, allowing the warming of the lowest part of the atmosphere, called troposphere, and the regulation of the climate of the Earth. Greenhouse gases (GHGs) triggered this phenomenon and continue to have a negative effect, along with water vapor and carbon dioxide.

However, since the Industrial revolution, the anthropic emissions of GHGs have increased by $40 \%$ for the $\mathrm{CO}_{2}, 150 \%$ for the $\mathrm{CH}_{4}$ and $20 \%$ for the $\mathrm{N}_{2} \mathrm{O}$ already causing evident consequences (IPCC Fifth Assessment Report, 2014). Although there can be time lapses and geographical shifts between emissions and impact on climate change, the IPCC defines "the warming of the unequivocal climate system", given the evident increase in global average air and ocean temperatures, widespread melting of snow and ice, and rising global average sea level" (Solomon et al., 2007).

The anthropogenic nature of climate change is established by many studies and models resumed in the IPCC Fifth Assessment Report (2014), in which natural and anthropogenic forcing are compared to the current land and ocean temperature increase. There is evidence greenhouse gases have induced a global mean surface warming likely to be in the range of $0.5^{\circ} \mathrm{C}$ to $1.3^{\circ} \mathrm{C}$ between 1951 and 2010 , considered the cooling effect of aerosols (IPCC Fifth Assessment Report, 2014). It has also been estimated that, in the same period, the contribution of GHGs emissions and other anthropogenic forcing implicated half of the observed increase in global average surface temperature (IPCC Fifth Assessment Report, 2014).

Furthermore, the level of $\mathrm{CO}_{2}$ in 2015 has reached for the first time the level of $400 \mathrm{ppm}$ in the atmosphere after 650,000 years of ranging between 140 ppm and 300 ppm (Dlugokencky \& Tans, 2015), mainly due to the economic development and the growth of population. More precisely, according to IPCC Fifth Assessment Report (2014) the largest total amount of GHGs net emissions in 2010 was released by the production of energy, accounting for $35 \%$. The second highest percentage, $24 \%$, is represented by the land use, including agriculture and forestry, which emit more than industry, transport and building, corresponding respectively to $21 \%, 14 \%$ and $6.4 \%$ of direct GHGs net emissions. 
In one hand, the increase of temperature causes complex consequences that affect the entire Earth ecosystem and induce numerous cascade effects, acting often as positive feedbacks of climate change. One of the most alarming effects occurs in the oceans, where the absorbed $\mathrm{CO}_{2}$ reacts with water and carbonate ion forming two bicarbonate ions, which have a central role in the $\mathrm{pH}$ buffering system. The considerable anthropic input of $\mathrm{CO}_{2}$ in the system induces high rates of bicarbonate ions formation in the ocean, unbalancing the biochemical equilibrium of the water. The acidification led by the $\mathrm{CO}_{2}$ input combined with the increase of water temperature have serious effects on the ocean system, such as changes in the thermohaline circulation, a decrease in the capacity of $\mathrm{CO}_{2}$ absorption, the rising of sea level, geographical shift of marine species and bleaching of coral reefs (Caldeira \& Wickett, 2003).

On the other hand, the terrestrial ecosystems are suffering the consequences of the global warming associated with the impact of extreme events, resulting in the melting of glaciers and permafrost, an increase of drought and floods, coastal erosion, alteration of water cycle, shift and/ or extinction of species, loss of biodiversity and loss of ecosystem services (IPCC Fifth Assessment Report, 2014).

The extreme weather events are already strongly threatening the agroecosystems and they are becoming more frequent and violent in particular in areas also previously interested by extreme weather conditions (Schär et al., 2004). Nevertheless, if the GHGs emissions are not reduced, the situation at the end of the century will become even worse due to the increase of the concentration of $\mathrm{CO}_{2}$ that, at high levels, reduce the plant productivity. Furthermore, the widespread temperature increase will enhance the decomposition speed and consequently decrease the soil organic stocks, which implies less fertility, loss of soil structure, less water retention capability, loss of biodiversity (Olesen et al., 2011). Finally, the modification of microclimates (warmer winters and summers) and the shifting of many species will result in more problems related to weeds, pests and plant diseases (Alcamo \& Olesen, 2012). 


\subsection{Land Degradation}

The Millennium Ecosystem Assessment (MEA, 2005) describes "land as a terrestrial ecosystem that includes not only soil resources, but also vegetation, water, other biota, landscape setting, climate attributes, and ecological processes that operate within the system, ensuring its functions and services". As defined by Alcamo et al. (2003), ecosystem provides supporting services (primary production, nutrient cycling and soil formation), provisioning services (e.g. foods and water) and regulating services (e.g. water regulation and purification, carbon sequestration, climate regulation).

However, the anthropic impact on land ecosystem is leading to a severe land degradation that is causing persistent reduction or loss of land ecosystem services (UNCCD, 2004; MEA, 2005), mainly caused by land mismanagement, such as intensive agricultural practices, inappropriate use of irrigation, overgrazing, deforestation or urban sprawl, and driven by underlying forces such as a weak implementation of policies, national and international market demand, and poverty (Geist, 2005). Bai et al. (2008) indicated that $24.53 \%$ of land is degraded and Nkonya et al. (2011) stated that developing countries, in particular, are affected by soil degradation. The report "The Value of Land" (2015) launched by the Economics of Land Degradation Initiative provides evidence on ecosystem services, value losses from land degradation, and estimates that the global loss of ecosystem service values may cost between 6.3 and 10.6 trillion USD.

Since land degradation induces long-term losses of ecosystem functions and productivity, the change in net primary productivity (NPP) and the deviation from the norm can be used as an indicator of land degradation or improvement (Bai et al., 2008). It has been calculated by Bai et al. (2008) that in the period 1981-2003 the loss of NPP due to land degradation, and consequently the $\mathrm{C}$ not removed from the atmosphere, amounted to $9.56 \cdot 10^{8}$ tons C. Furthermore, land degradation implicates a decrease in crop and forest production, an increase in floods and droughts, the loss of biodiversity and habitats, the alteration of water cycle, nutrients cycle and sedimentation. 


\section{A reverse vision of ecosystem}

The collective consciousness generally considers the ecosystem as a passive set that has to be protected for its beauty and preciousness. But rarely it is recognized as a set of interacting components able to release both energy and services. Indeed, under the United Nations Convention on Biological Diversity (CBD, 1992), an ecosystem is defined as "a dynamic complex of plant, animal and micro-organism communities and their nonliving environment interacting as a functional unit." This definition stresses function rather than scale: an ecosystem is not defined in terms of its size, but rather by the fact that it is a functional unit.

Therefore, from this point of view it will become clear that the innovation necessary to face urgent issues regarding the environment, like climate change, could derive from the environment itself.

In this perspective, where the situation turns upside down, the ecosystem takes an active part in the adaptation process to cope with climate change and in the mitigation of the GHGs emissions.

\subsection{Sustainable Food}

The ecosystem represents a direct fundamental source of food, in particular for indigenous and poor people living in developing countries. When communities of plants and animals interacting with their physical and chemical environments are modified by people to produce food, fiber, fuel and other products for human consumption and processing, an agroecosystem takes shape (Altieri, 2002). Agroecology is a branch of knowledge that studies and emphasizes the interrelatedness of all agroecosystem components and the complex dynamics of ecological processes (Vandermeer, 1995). From this point of view, a healthy agroecosystem is not only a source of food (provisioning service), but it can also improve nutrient cycling and soil formation (supporting services), water regulation and purification, carbon sequestration and climate regulation (regulating services).

\subsection{Climate-Smart Agriculture}

The challenge for people managing the agroecosystem is to produce food or other goods, while maintaining the ability of ecosystem to develop 
supporting and regulation services. For this reason, the study in-depth of the environment, the microclimate and the soil is essential to identify and choose the most suitable practices to improve services and consequently to increase crops.

However, nowadays farmers are deeply affected by the increased climate variability that strongly enhances the production risks and challenges farmers' coping ability (Thornton \& Gerber, 2010). Poor farmers are particularly damaged by the impact of climate change because they often are landless and marginalized ethnic groups (Olsson, et al., 2014).

Climate-smart agriculture (CSA) is a new approach, which aims to face the climate change wicked problem "identifying synergies and tradeoffs among food security, adaptation and mitigation as a basis for informing and reorienting policy" (Lipper et al., 2014).

CSA is summarized in three objectives: 1) sustainable increasing agricultural productivity to support equitable increases in incomes, food security and development; 2) adapting and building resilience to climate change from the farm to national levels; and 3) developing opportunities to reduce GHGs emissions from agriculture compared with past trends (FAO, 2013).

As discussed by Lipper et al. (2014), even if CSA aims to attain all three objectives, it is not possible to achieve the "triple win" solution everywhere. During the building of locally-acceptable solutions it is essential to consider short to long time horizons and to evaluate the project from local to global scales. Moreover, the importance of each objective changes across locations and situations, especially because different circumstances generate particular synergies and trade-offs.

The reduction of GHG emissions represents an awkward problem particularly in the developing and poor countries because on the one hand they have contributed to triggering the climate change on a much lower scale and on the other hand they are now mainly affected by the impacts on a much broader scale. Moreover, even if mitigation can improve food security and adaptation, additional costs may be necessary in order to make this benefit possible. From this point of view, the comparison between the costs of low-emission growth strategies and the conventional high-emission 
growth paths can increase the development of mitigation practices in agriculture supported by climate finance (Lipper et al., 2014).

\subsection{Agroforestry}

One of the agricultural practices that most attains all three objective of CSA and generates a "triple win" solution is agroforestry, defined by the International Centre for Research in Agroforestry (2000) as "a dynamic, ecologically based natural resource management practice that, through the integration of trees and other tall woody plants on farms and in the agricultural landscape, diversifies production for increased social, economic, and environmental benefits".

Agroforestry system types include: silvopasture, alley cropping, multilayer tree gardens, home gardens, multipurpose trees on croplands or shelterbelts, where widely spaced rows of trees are planted between annual crops or windbreaks and buffer strips in different ways (Nair, 1993).

Even if growing trees with agricultural crops was a common practice since the domestication of plants and animals (Smith, 1929; King, 1987; Williams et al., 1997), the term 'agroforestry' was first used in the publication titled Trees, Food and People - Land Management in the Tropics (Bene et al., 1977), where the authors described its benefits for soil conservation and improvement of productivity. As a result, the International Council for Research in Agroforestry (ICRAF) was established in 1977 in Nairobi (Kenya), with the aim of promoting sustainable land-use management in both tropical and temperate latitudes.

In contrast with monoculture, agroforestry practices are characterized by high level of biodiversity and include numerous species of plants that can support many provisioning services relating to human and animal nutrition (fruit, nuts, oils and leaves, fodder trees for livestock), timber and wood energy, medicinal products and special materials (gums, resins and latex products).

However, on a global and long-lasting scale the most remarkable class of services given by forests and agroforests are the supporting and the regulating services.

In the tropics, farmers imitated vertical forest structures by planting a variety of crops with different growth habits, resulting in a high species 
diversity on a mall land area (Kass \& Somarriba, 1999). This system, recreating a situation that is very similar to natural environment, is able to protect the soil from erosion by reducing the impact from raindrops, and is also able to increase the organic material provided by litter from trees (Oelbermann et al., 2004). In the tropics, agroforestry land management practices maintain landowner self-sustenance (Huxley, 1999), whereas in temperate latitudes the focus is on resource management policies, farming technology, labor costs and real estate values (Williams et al., 1997). However, in both biomes, trees are viewed as an integral part of agroforestry with the potential to restore degraded lands, to maintain soil fertility, and more recently to sequester $\mathrm{C}$ for mitigating atmospheric $\mathrm{CO}_{2}$ emissions.

\section{Complex Systems and Wicked Problems}

Forests are probably the most common examples of complex adaptive ecosystems. A complex adaptive system is characterized by multiple spatial and temporal scales interactions between system components, so that the overall outcome is not easy to predict. In the case of forests, we know the individual system components and their interactions, such as trees, need light, water, and nutrients to grow, and they may compete with each other for these resources. However, it is much more difficult to predict precisely the global development and the evolution of the entire ecosystem.

In complex adaptive system "complexity emerges from a small set of critical processes that create and maintain the self-organizing properties of the system's interacting components so that even if some parts are lost/ damaged the system as a whole may continue to exist" (Holling, 2001). Thus, a forest adapts to changes in conditions. For example, some plants developed the ability to respond to the attack of insect herbivores by releasing chemicals that attract the natural predators of these insects (for example, when wild tobacco plants are attacked by herbivores such as the hawkmoth larva, they release volatile organic compounds that attract predatory insects; Kessler \& Baldwin, 2001).

It is said that Complex adaptive systems have memory: how they change and adapt will be determined by their initial state and by the disturbances they have suffered. A complex system is not necessarily complicated because it often consists of simple interactions and simple rules that regulate the relationships between interacting components, 
even if the whole system is greater than the sum of all its parts. However, while we can often identify the main structural rules that define a system, it is more difficult to predict outcomes of the collective behavior of its components. In summary, complex adaptive systems are characterized by emergent properties and self-organization as well as by indeterminacy and path-dependency (Holling, 2001).

Complex adaptive systems are often interested by so-called wicked problems. A complex problem is characterized by "no definitive formulation, no stopping rule, and no test for a solution" (Berkes, 2004). Thus, an approach that points the attention only on the individual components will not be sufficient to solve a wicked problem. A systems approach, in contrast, considers the problem in terms of the whole, focusing on the interaction between the parts of the system, and even between the surrounding systems (Waltner-Toews et al., 2008).

Along with system thinking, adaptive management is crucial in addressing wicked problems. Adaptive management is a systematic process to constantly adjust policies and practices by learning from the outcome of previously used policies and practices (Holling, 1978), summarized by the concept of "Learning from experience". The adaptive management cycle includes four stages: (1) planning, (2) carrying out the plan, (3) monitoring, and (4) interpreting the monitoring results so that a new plan can be developed and, hopefully, more appropriate (Holling, 1978).

Currently, the biggest problem we face is the climate change, since climate is an open, self-organizing and complex system of adaptation. The main form in the climate system is self-regulating in the feedback loops. However, if these feedback mechanisms were not in place, global warming would continue to be roughly proportional to the emitted amount of carbon dioxide. In addition, the presence of these feedback loops could lead to 'thresholds' or 'tipping points' in which small changes could result in a disproportionate amount of warming and associated climate system responses (Lenton et al., 2008).

In this context agroforestry does not aim to solve the perverse problem of climate change. Instead, it represents an attempt to implement the adaptive management in agroecosystems, developed through the systemic thinking approach that considers the interactions between the parts of the 
system while maintaining the vision of the whole rather than focusing on individual components.

\subsection{Improving soil quality through agroforestry}

The main objectives of United Nations Convention to Combat Desertification (UNCCD) is to promote soil preservation, support the restoration of degraded lands and to disseminate knowledge of land services by the Sustainable Land Management (SLM). The SLM was developed during the 1992 Earth Summit and focuses on the concepts of productivity, resilience, protection, economic viability, and social acceptability (Smyth \& Dumanski, 1993), which can be achieved through maintaining and enhancing soil cover, reducing topsoil disturbance and compaction, rotating and interplanting crops/plants, integrating crop and livestock systems, enhancing the diversity of plants and animal species, and balancing extraction and replenishment of nutrients(Liniger et al., 2011).

Agroforestry practices include many important aspects of sustainable land management through which soil quality can be improved. The case study of the middle central hills of Nepal (Kaule), a region characterized by high level of erosion and acidic soil, developed by Schwab, Schickhoff and Fischer (2015) describes in detail the improvements in soil characteristics due to agroforestry (AF) compared to the conventional system (CS), mainly cultivated with monoculture, and the system of transition to agroforestry (TS).

The data collected by Schwab et al. (2015) show that the soil chemical parameters of AF are generally superior to the CS fields, which indicates a higher soil quality and more fertile soil conditions. In specific, the soil $\mathrm{pH}$ has been raised by the increase of organic matter from lopped or natural fallen litter and plant material metabolized by cattle, since humus is an important buffer and reduces the fluctuations in soil acidity (Bot $\&$ Benites, 2005; Brady \& Weil, 2014).

Moreover, the organic matter content is crucial in achieving more fertile conditions by enhancing the soil capacity to store water and available macro and micro nutrients, and by reducing susceptibility to erosion (Schwab et al., 2015). Agricultural soils with a high content of organic 
matter and, therefore, a high $C$ content can function as carbon sinks (Bot $\&$ Benites, 2005; Fageria, 2012; Thorne \& Tanner, 2002).

The Higher content of organic matter content in AF soils could also provide better control of phytophagous pests by facilitating antagonists (cf. Fageria, 2012; Martin \& Sauerborn, 2013). The organic matter combined with farm manure is capable of abducting $\mathrm{Al}_{3+}$ in a complex way, blocking the toxic effect and supporting the growth of the plants despite the low $\mathrm{pH}$ (Fageria, 2012).

Baseline saturation of all FA samples exceeds $80 \%$ and is in the "optimal" range (Kuntze et al., 1994), a major difference compared to other agricultural sites in Nepal (von Westarp et al., 2004).

Significantly higher total nitrogen $(\mathrm{Nt})$ of AF field soils compared to CS and TS soils has been detected during the analysis of Schwab et al. (2015) and has been attributed to higher organic matter content and the comparatively excessive cultivation of legume species (Fabaceae) in the AF system, in terms of both species richness and number of individuals

Another study realized by Newaj, Chaturvedi and Handa (2016) from the ICAR-Central Agroforestry Research Institute, India, analyses the role of traditional large cardamom (Amomum subulatum) agroforestry system on enhancing the ecosystem services in the Eastern Himalayas. It has been observed that the large agroforestry system based on cardamom accelerates the cycle of nutrients, increases soil fertility and productivity, reduces soil erosion, conserves biodiversity, conserves water and soil, and serves as a carbon sink.

Other examples of improved soil quality through agroforestry have been identified in many regions of Africa by Marques et al. (2016) in a review on multifaceted impacts of Sustainable Land Management in drylands.

In semi-arid Niger, agroforestry practices have expanded spontaneously to more than $50,000 \mathrm{~km}^{2}$ since the 1980s (Rinaudo, 2011). In particular the crushing technique of pruned leaves left on the surface reduces erosion and increases the nutrients cycle and carbon back to the soil.

In humid tropical forest ecosystems, the relationship between trees and crops is fundamental, since the high productivity of the plants is based 
on the rapid recycling of nutrients between the plant community and the poor soil (Martinelli et al., 1999). Legume trees that form dinitrogening symbioses with rhizobia are common in humid tropical agroforestry, which often form the main source of $\mathrm{N}$ in low-input systems (Nygren et al., 2015). A well-informed benefit of legume trees is the increase in microbial carbon and nitrogen content and in soil compare to monocultures (Sierra et al., 2002), which results in a long-term accumulation of $C$ and $N$ in soils (Haggar et al., 1993, Dulormne et al., 2003, Soto-Pinto et al., 2010).

\subsection{Biodiversity increases resilience and productivity}

Biodiversity, that is, the abundance and richness of species, plays fundamental roles in processes and services of vital ecosystems, such as increasing productivity, controlling agricultural pests and slowing the spread of diseases (Sileshi et al., 2007). Unfortunately, soil biodiversity is even more endangered due to the loss of habitat caused mainly by deforestation and land degradation. In addition, climate change makes the conservation of biological diversity a global priority (Korn et al., 2003).

In this context, agroforestry is often considered an alternative land use strategy that offers solution to land and forests degradation and loss of biodiversity (Oke \& Odebiyi, 2007). Schroth (2004) identified three roles of agroforestry in the conservation of biodiversity on a landscape scale: "the provision of complementary and secondary habitat for species that tolerate a certain level of disturbance; the reduction of natural habitat conversion rates in certain cases; and the creation of a more benign and permeable 'matrix' among remnants of habitat compared to land uses less dominated by trees, which can support the integrity of these remnants and the conservation of their populations".

Moreover, practices such as the mixture of woody plants in crops, fodder and livestock have direct effects on the resistance of the system thanks to the diversification of crops produced seasonally, as well as the greater efficiency in the use of resources (Olson et al., 2000).

Huang et al. (2002) found a significant positive impact of agroforestry on biodiversity conservation of natural reserves in Tanzania, particularly under climate change. The reason identified by Syampungani et al. (2010) is that the higher the number of different species or varieties present in 
fields or in agroecosystems, the greater the probability that at least some of them can cope with changing environment. For example, during droughts deep-rooted trees allow better access to nutrients and water than annual crops (van Noordwijk et al., 1996).

Another common case of enhancement of resilience through biodiversity is related to pest control. In warmer temperatures, insect pests and plant diseases are expected to increase due to range expansion, higher winter survival, and increased number of generations per season (USGCRP, 2009), therefore increasing opportunities for biological control of pests will become increasingly important and could be achieved through agroforestry (Dix et al., 1995). Stamps and Linit (1997) reported that the greater niche diversity of agroforestry can support even greater numbers and/or diversity of populations of naturalenemies than polycultural systems of annual crops or monocultures. Taking the research done by Stamps et al. (2002) as an example, it was proved that alfalfa intercropped with walnut supported twice as many predators and parasitic hymenoptera and half as many herbivores as did alfalfa alone. Also in the study of Piotto et al. (2003) the best growth was demonstrated in a mixed system of 13 native species by comparing pure and mixed plantations in the dry tropics of Costa Rica. Mixed plantations with native species would also contribute to sustainable management because they provide a greater range of goods and services than pure species plantations.

Having said that, Schroth et al. (2004) focused on the feasibility of synergistic effects of forest conservation in parks or conservation concessions and the promotion of agroforestry land uses in the surroundings. They affirm that the development of such synergies to a large extent depends on good governance, especially sound environmental legislation and its effective enforcement, and institutions that allow and engage in integrated approaches to conservation and rural development planning. Thus, under particular scenarios and in combination with other measures, the hypothesis that states the decrease of deforestation through the increase of agroforestry in land use appears to be valid, although more empirical work is needed to clarify the range of social and economic conditions under which its validity is maintained (Schroth et al., 2004). 


\subsection{Carbon sequestration and mitigation of GHGS emissions}

As already discussed, the most problematic objective that Climate Smart Agriculture sought to accomplish is the reduction of GHGs emissions from agriculture.

Of all the land uses analyzed in the Land-Use, Land-Use Change and Forestry report of the IPCC (2000), agroforestry offered the highest potential for carbon sequestration in non-Annex I countries. Agroforestry has such a high potential, not because it is the land use practice with the highest carbon density, but because there is such a large area that is susceptible for the land use change (Verchot et al., 2007).

Compared to monocultures agroforestry systems have a direct nearterm (decades or centuries) C storage capability in aboveground biomass (i.e., stem, branch, and foliage) and in belowground biomass (i.e., roots, and in soil), and have the potential to offset immediate greenhouse gas emissions associated with deforestation and shifting cultivation (Dixon, 1995).

Specifically, direct $C$ inputs to the soil can potentially be increased by some agroforestry practices, such as returning prunings of woody species to the soil as mulch and allowing abundant tree litter to decompose on site, allowing livestock to graze and add dung to the soil, allowing woody species to grow and add surface and belowground litter during crop fallow phases, integrating trees and their litter input in animal production systems, allowing litter inputs to the soil from shade-tolerant species growing under trees, and benefiting from the soil $\mathrm{C}$ inputs of agricultural crops grown during early stages of the establishment of forestry plantations (Schoeneberger et al., 2012).

Nair et al. (2010) calculated that between 30 and $300 \mathrm{Mg}$ C/ha may be stored in agroforestry soils up to $1 \mathrm{~m}$ depth. Global estimates for the $\mathrm{C}$ sequestration potential of agroforestry systems over a 50-year period range between 1.1 and 2.2 Pg C/year but, in particular, estimates of land area are highly uncertain (Dixon, 1995), even because the above- and belowground vegetation C sequestration potential is highly variable (Nair et al., 2009).

The woody biomass component represents the major portion of easily observed and measured new $C$ to the system (Schoeneberger, 2009). The bulk of this $C$ is generally contained within the aboveground 
woody portion (trunk and branches). For example, Peichl et al. (2006) found that the aboveground woody biomass $\mathrm{C}$ in hybrid poplar (Populus deltoids X Populus nigra) and Norway spruce (Picea abies L.) comprised approximately $82 \%$ and $79 \%$, respectively, of the total woody biomass $\mathrm{C}$ in a 13-year-old alley cropping system.

Furthermore, there are factors that influence the storage of $C$ in agroforestry, including system management (i.e. conservation tillage), use of groundcovers, fallowing, system age and design (i.e. tree densities), and tree species utilized. Nevertheless, comparing these systems, $C$ stocks and pools vary between tree ages but do not vary significantly between temperate and tropical systems of similar age (Oelbermann et al., 2004).

However, to be accurate we have to consider that agroforestry plantings, compared to forests, have a more open environment, resulting in trees with greater branch production and greater specific gravity (Zhou et al., 2011), so the use of existing forest-derived equations may not accurately estimate woody biomass C (Schoeneberger et al., 2012).

In conclusion, along with the GHGs mitigation value, increasing SOC is associated with enhanced $C$ and nutrient cycling, vigorous soil fauna, optimal soil structure, and improved soil water regimes (Doran et al. 1994).

\subsection{Adaptation to extreme events and drought}

Extreme events, and drought in particular, are probably the most dangerous outcomes of climate change affecting agriculture in virtually all regions.

The presence of trees in the agroecosystem can effectively modify the microclimate (Charbonnier et al., 2013) and, if well managed, increase resilience (Nguyen \& Hoang, 2013) during adverse conditions because it improves water balance at a local level, such as interception, transpiration, infiltration, surface runoff and soil evaporation. Practices such as windbreaks, alley-cropping systems, and riparian buffers can significantly improve the microclimate and reduce the impacts of climate change (Garrett, 2009).

In agroforests the porosity of the soil, and therefore permeability, is enhanced by the characteristic deep root systems, which positively affect the infiltration of soil water (Ilstedt et al., 2007). In addition to this, deep root systems help to retain water in the topsoil or surface soil, as they generally 
produce more residues than other cover types and high soil organic matter content is able to hold more water than poor soil (El-Swaify, et al., 1983).

Furthermore, trees increase evapotranspiration because of canopy interception and the uptake of water in the root zone. Ellison et al. (2012) stated that, at a larger regional or global context, forest-water interactions play a pivotal role in supplying the atmospheric moisture that becomes precipitation in the hydrologic cycle. Without forests and wetlands, precipitation will decrease significantly, in particular during summertime. Lott et al. (2003) reported that about 25\% of the water that transpires from trees gets used during the dry season, indicating that they are able to utilize off-season rainfall (comprising 15-20\% of the total annual rainfall) and residual soil water after the cropping period.

The shading effects of agroforestry trees can buffer temperature and atmospheric saturation deficit, reducing exposure to supra-optimal temperatures, under which physiological and developmental processes and yield become increasingly vulnerable (Lott et al., 2009). Scattered trees in agroforestry farms can enhance the understory growth by reducing incident solar radiation, air and soil temperature, while improving water status, gas exchange and water use efficiency (Bayala et al., 2009).

Field studies have shown that when air and soil temperatures are too cold or too warm for forage growth, they can be favourably modified by trees in silvopasture systems to create an extended production period (Feldhake 2002). Using a process-based model, Easterling et al. (1997) showed that windbreaks would increase dryland maize yields in Nebraska above corresponding unsheltered yields for most levels of predicted climate change.

During periods of excessive soil moisture, tree-based systems can maintain aerated soil conditions by pumping out excess water more rapidly than other production systems, and when flooding eliminates an herbaceous crop for a season, the woody component can often survive and offer an economic return (Dimitriou et al. 2009).

On the other hand, plant stress, as well as shifts in woody plant disease, pest and natural enemy dynamics created by extreme weather conditions, and the longer-term predicted shifts in climate, will play a dominant role in the persistence and performance of all herbaceous or woody agroforestry 
plants (Fuhrer, 2003). Thus, it is fundamental to identify which agroforestry species may be more suited to future conditions and develop the CCintegrated planning and design process (Schoeneberger, et al., 2012).

An example of research on this issue is described by Schwendenmann et al. (2010), who studied the species-specific physiological mechanisms and traits of several plants able to cope relatively well with reduced soil water availability. They found indications that in the cacao/Gliricidia agroforests the competition between cacao and Gliricidia for soil water resources is limited, and that the shade trees may even help the system to cope with droughts. Cacao/Gliricidia agroforests may thus play a critical role in minimizing the vulnerability of farmers' livelihood to extreme weather events such as droughts (Schwendenmann, et al., 2010).

Another example is given by Ilstedt et al. (2016). They developed and tested an optimum tree cover theory in which groundwater recharge is maximized at an intermediate tree density. Below this optimal tree density the benefits from any additional trees on water percolation exceed their extra water use, leading to increased groundwater recharge, while above the optimum the opposite occurs. Their results, based on groundwater budgets calibrated with measurements of drainage and transpiration in a cultivated woodland in West Africa, demonstrate that groundwater recharge was maximized at intermediate tree densities. Therefore, a relatively regular well-spaced tree distribution may be preferable to a random or aggregated one, even though tree size, age and species that affect transpiration will also have an influence.

\section{Conclusions}

Agroforestry represents an extraordinary resource for the management of agroecosystems, to implement a proactive approach, specifically in relation to adaptation to climate change and generally to improve the environmental condition of a specific area.

The aim of agroforestry to increase social, economic, and environmental benefits can be reached through an in depth study established in the region that focuses on the characteristics of soil and climate, as well as the main risks and impacts that affect the socio-ecological system. 
The preparedness and the adaptive management in the development of agroforestry practices can lead to a remarkable enhancement of life condition, a substantial improvement of agroecosystems and an increase of yields. These positive outputs are particularly significant in the developing countries, where there is a strong need to strengthen the Climate Smart Agriculture practices, such as agroforestry, with the objective to growth the yield in the most sustainable way for the community and for the environment.

Thus, it is fundamental that the science solutions go at the same pace with the policies development. The policies implementation created on the base of the study of sustainable practices can greatly accelerate and encourage their adoption.

\section{References}

Alcamo, J., \& Olesen, J. E. (2012). Life in Europe under climate change. John Wiley \& Sons, Ltd.

Bai, Z. G., Dent, D. L., Olsson, L., \& Schaepman, M. E. (2008). Proxy global assessment of land degradation. Soil use and management, 24(3), pp. 223-234.

Bayala, J., Heng, L. K., van Noordwijk, M., \& Ouedraogo, S. J. (2008). Hydraulic redistribution study in two native tree species of agroforestry parklands of West African dry savanna.acta oecologica,34 (3), pp. 370-378.

Bene, J. G., Beall, H. W., \& Côté, A. (1977). Trees, food, and people: land management in the tropics. IDRC.

Benegas, L., Ilstedt, U., Roupsard, O., Jones, J., \& Malmer, A. (2014). Effects of trees on infiltrability and preferential flow in two contrasting agroecosystems in Central America. Agriculture, Ecosystems \& Environment, 183, pp. 185-196.

Berkes, F. (2004). Rethinking community based conservation. Conservation Biology 18(3), pp. 621-630.

Bot, A., \& Benites, J. (2005). The importance of soil organic matter: Key to drought-resistant soil and sustained food production (No. 80). Food \& Agriculture Org. 
Brady, N. C., \& Weil, R. (2013). Nature and Properties of Soils, the: Pearson New International Edition. Pearson Higher Ed.

Caldeira, K., \& Wickett, M., (2003). Anthropogenic carbon and ocean ph. Nature, pp. 425, 365.

Campbell, B. M., Vermeulen, S. J., Aggarwal, P. K., Corner-Dolloff, C., Girvetz, E., Loboguerrero, A. M., ... \& Wollenberg, E. (2016). Reducing risks to food security from climate change. Global Food Security. Food and Agriculture Organization of the United Nations (FAO). (2009). The State of Food Insecurity in the World: Economic crises-Impacts and Lessons Learned 8-12 (FAO).

CDB. 1992. Convention on biological diversity (Article 2).

Charbonnier, F., le Maire, G., Dreyer, E., Casanoves, F., Christina, M., Dauzat, J., Eitel, J. U. H., Vaast, P., Vierling, L. A., \& Roupsard, O., (2013). Competition for light in heterogeneous canopies: application of MAESTRA to a coffee (Coffea Arabica L.) agroforestry system. Agric. For. Meteorol. 181, pp. 152-169.

De Groot, R., Brander, L., Van Der Ploeg, S., Costanza, R., Bernard, F., Braat, L., ... \& Hussain, S. (2012). Global estimates of the value of ecosystems and their services in monetary units. Ecosystem services, 1(1), pp. 50-61.

Dlugokencky, E., \& Tans, P. (2015). "ESRL Global Monitoring Division". Earth System Research Laboratory. National Oceanic \& Atmospheric Administration. Retrieved 7 May 2015.

Doran, J. W., Coleman, D. C., Bezdicek, D. F., \& Stewart, B. A. (1994). Defining Soil Quality for a Sustainable Environment, Madison, WI: Soil Science Society of America, Inc.

Dulormne, M., Sierra, J., Nygren, P., \& Cruz, P. (2003). Nitrogen-fixation dynamics in a cut-and-carry silvopastoral system in the subhumid conditions of Guadeloupe, French Antilles. Agroforestry Systems, 59(2), pp. 121-129.

Easterling, W. E., Hays, C. J., Easterling, M. M., \& Brandle, J. R. (1997). Modelling the effect of shelterbelts on maize productivity under climate change: an application of the EPIC model. Agriculture, Ecosystems and Environment 61, pp. 163-176 
El-Swaify, S. A., Walker, T. S., \& Virmani, S. M. (1984). Dryland management alternatives and research needs for Alfisols in the semi-arid tropics.

ELD Initiative. (2015). The value of land: Prosperous lands and positive rewards through sustainable land management. The Economics of Land Degradation, Bonn, Germany.

Ellison, D., Futter, M., \& Bishop, K. (2012). On the forest cover-water yield debate: from demandto supplyside thinking. Global Change Biology, 18(3), pp. 806-820.

Fageria, N. K. (2012). Role of soil organic matter in maintaining sustainability of cropping systems. Communications in Soil Science and Plant Analysis, 43(16), pp. 2063-2113.

FAO (2011). The State of the World's Land and Water Resources for Food and Agriculture (SOLAW) - Managing Systems at Risk. Food and Agriculture Organization of the United Nations: Rome, Italy; Earthscan, London, UK; pp. 112-113.

Feldhake, C. M. (2002). Forage frost protection potential of conifer silvopastures . Agricultural and forest meteorology, 112(2), pp. 123-130.

Food and Agriculture Organization of the United Nations (FAO). (2013). Executive summary. Climate-Smart Agriculture Sourcebook (FAO, Rome).

Fuhrer, J. (2003). Agroecosystem responses to combinations of elevated CO 2, ozone, and global climate change. Agriculture, Ecosystems \& Environment, 97(1), pp. 1-20.

ICRAF. (2000). Paths to prosperity through agroforestry. ICRAF's corporate strategy, 2001-2010. Nairobi: International Centre for Research in Agroforestry.

Ilstedt, U., Tobella, A. B., Bazié, H. R., Bayala, J., Verbeeten, E., Nyberg, G., ... \& Sheil, D. (2016). Intermediate tree cover can maximize groundwater recharge in the seasonally dry tropics. Scientific reports, 6 .

International Fund for Agricultural Development (IFAD). Rural Poverty Report 2011. (IFAD, Rome, 2011). 
IPCC. (2000). Land-use, land-use change and forestry. Special report of the intergovernmental panel on climate change. Cambridge University Press, UK, p. 375.

IPCC. (2014). Climate Change 2014: Impacts, Adaptation, and Vulnerability. Part A: Global and Sectoral Aspects. Contribution of Working Group II to the Fifth Assessment Report of the Intergovernmental Panel on Climate Change [Field, C.B., V.R. Barros, D.J. Dokken, K.J. Mach, M.D. Mastrandrea, T.E. Bilir, M. Chatterjee, K.L. Ebi, Y.O. Estrada, R.C. Genova, B. Girma, E.S. Kissel, A.N. Levy, S. MacCracken, P.R. Mastrandrea, and L.L. White (eds.)]. Cambridge University Press, Cambridge, United Kingdom and New York, NY, USA.

Kass, D. C. L., \& Somarriba, E. (1999). Traditional fallows in Latin America. Agroforestry Systems, 47(1-3), pp. 13-36.

Kessler, A., \& Baldwin, I. T. (2001). Defensive function of herbivore-induced plant volatile emissions in nature. Science, 291(5511), pp. 2141-2144.

King, K. F. S. (1987). The history of agroforestry. In: Steppler, H. A, Nair, P .K. R. (Eds.), Agroforestry: A Decade of Development. International Council for Research in Agroforestry (ICRAF), Nairobi, Kenya, pp. $3-13$.

Korn, H., Ntayombya, P., Berghall, O., Cotter, J., Lamb, R., Ruark, G., \& Thompson, I. (2003). Climate change mitigation and adaptation options: Links to, and impacts, on biodiversity. In Interlinkages between biological diversity and climate change: Advice on the integration of biodiversity considerations into the implementation of the United Nations Framework Convention on Climate Change and its Kyoto protocol, pp. 48-87. CBD Technical Series no. 10. Montreal, Canada: Secretariat of the Convention on Biological Diversity.

Kuntze, H., Roeschmann, G., \& Schwerdtfeger, G. (1994). Bodenkunde (Vol. 5). Stuttgart: Ulmer.

Lal, R. (2005). Forest soils and carbon sequestration. Forest ecology and management, 220(1), pp. 242-258.

Liniger, H., Mekdaschi-Studer, R., Hauert, C., \& Gurtner, M. (2011). Guidelines and best practices for Sub-Saharan Africa, field application. FAO. 
Lipper, L., Thornton, P., Campbell, B. M., Baedeker, T., Braimoh, A., Bwalya, M. ... \& Hottle, R. (2014). Climate-smart agriculture for food security. Nature Climate Change, 4(12), pp. 1068-1072.

Lobell, D. B., Schlenker, W., \& Costa-Roberts, J. (2011). Climate trends and global crop production since 1980. Science, 333(6042), pp. 616-620.

Locatelli, B., Kanninen, M., Brockhaus, M., Colfer, C. P., Murdiyarso, D., \& Santoso, H. (2008). Facing an uncertain future: How forests and people can adapt to climate change.

Lott, J. E., Khan, A. A. H., Black, C. R., \& Ong, C. K. (2003). Water use in a Grevillea robusta-maize overstory agroforestry system in semi-arid Kenya. Forest ecology and management, 180(1), pp. 45-59.

Lott, J. E., Ong, C. K., \& Black, C. R. (2009). Understorey microclimate and crop performance in a Grevillea robusta-based agroforestry system in semi-arid Kenya. Agricultural and forest meteorology, 149(6), pp. 1140-1151.

Marques, M. J., Schwilch, G., Lauterburg, N., Crittenden, S., Tesfai, M., Stolte, J. ... \& Karkani, A. (2016). Multifaceted impacts of sustainable land management in drylands: A review. Sustainability, 8(2), p. 177.

Martin, K., \& Sauerborn, J. (2013). Agroecology. Amsterdam, the Netherlands: Springer.

Martinelli, L. A., Piccolo, M. C., Townsend, A. R., Vitousek, P. M., Cuevas, E., McDowell, W. ... \& Treseder, K. (1999). Nitrogen stable isotopic composition of leaves and soil: tropical versus temperate forests. In New Perspectives on Nitrogen Cycling in the Temperate and Tropical Americas (pp. 45-65). Springer Netherlands.

Millennium Ecosystem Assessment. (2005). Ecosystems and Human Well-being: Synthesis. Island Press, Washington, DC.

Nair P. K. R., Kumar B. M., Nair V. D. (2009) Agroforestry as a strategy for carbon sequestration. J Plant Nutr Soil Sci 172, pp. 10-23.

Nair, P. K. R., Nair, V. D., Kumar, B. M., \& Showalter, J. M. (2010). Chapter five-carbon sequestration in agroforestry systems. Advances in agronomy, 108, pp. 237-307. 
Nasi, R., Wunder, S., \& Campos, J. J. (2002). Forest ecosystem services: can they pay our way out of deforestation?

Newaj, R., Chaturvedi, O. P., \& Handa, A. K. (2016). Recent development in agroforestry research and its role in climate change adaptation and mitigation. Indian Journal of Agroforestry, 18(1), pp. 1-9.

Nguyen, Q., Hoang, M. H., Öborn, I., \& Noordwijk, M. V. (2013). Multipurpose agroforestry as a climate change resiliency option for farmers: an example of local adaptation in Vietnam. Climatic Change, 117 , pp. 241-257.

Nkonya, E., Gerber, N., Baumgartner, P., von Braun, J., De Pinto, A., Graw, V., et al. (2011). The economics of desertification, land degradation, and drought - Toward an integrated global assessment. ZEF Discussion Papers on Development Policy No. 150, Center for Development Research (ZEF).

Nygren, P., \& Leblanc, H. A. (2015). Dinitrogen fixation by legume shade trees and direct transfer of fixed $\mathrm{N}$ to associated cacao in a tropical agroforestry system. Tree physiology, 35(2), pp. 134-147.

Oelbermann, M., Voroney, R. P., \& Gordon, A. M. (2004). Carbon sequestration in tropical and temperate agroforestry systems: a review with examples from Costa Rica and southern Canada. Agriculture, ecosystems \& environment, 104(3), pp. 359-377.

Oke, D. O., \& Odebiyi, K. A. (2007). Traditional cocoa-based agroforestry and forest species conservation in Ondo State, Nigeria. Agriculture, ecosystems \& environment, 122(3), pp. 305-311.

Olesen, J. E., Trnka, M., Kirshenbaum, K. C., Skjelvåg, A. O., Seguin, B., Peltonen - Saino, P., Rossi, F., Kozyra, J., Micale, F. (2011). Impacts and adaptation of European crop production systems to climate change. European Journal of Agronomy 34, pp. 96 - 112 .

Olson, R. K., Schoeneberger, M. M., \& Aschmann, S. G. (2000). An ecological foundation for temperate agroforestry. In North American Agroforestry: An Integrated Science and Practice, eds. H.E., Garrett, W.J., Rietveld, \& R.F., Fisher, pp. 31-62. Madison, WI: American Society of Agronomy, Inc.

Olsson, L. et al. (2014). Livelihoods and poverty. Climate Change 2014: Impacts, Adaptation, and Vulnerability. Part A: Global and Sectoral 
Aspects. Working Group II Contribution to the Fifth Assessment Report of the Intergovernmental Panel on Climate Change. (Cambridge Univ. Press, Cambridge, UK and New York).

Pearce, David W. (2001). The economic value of forest ecosystems. Ecosystem health 7.4 (2001), pp. 284-296.

Peichl, M., Thevathasan, N. V., Gordon, A. M., Huss, J., \& Abohassan, R. A. (2006). Carbon sequestration potentials in temperate tree-based intercropping system.

Piotto, D., Viquez, E., Montagnini, F., \& Kanninen, M. (2004). Pure and mixed forest plantations with native species of the dry tropics of Costa Rica: a comparison of growth and productivity. Forest Ecology and Management, 190(2), pp. 359-372.

Reuveny, R. (2007). Climate change-induced migration and violent conflict. Political geography, 26(6), pp. 656-673.

Rinaudo, T. (2011). Farmer managed natural regeneration. Niger. In Sustainable Land Management in Practice-Guidelines and Best Practices for Sub-Saharan Africa: TerrAfrica; Liniger, H.P., Mekdaschi Studer, R., Hauert, C., Gurtner, M., Eds.; World Overview of Conservation Approaches and Technologies (WOCAT): Wageningen, The Netherlands, 2011; Food and Agriculture Organization of the United Nations (FAO): Rome, Italy, 2011; pp. 138-139.

Schär , C. , Vidale, P. L. , Lüthi, D. , Frei, C. , Häberli, C. , Liniger , M. A. , $\&$ Appenzeller, C. (2004). The role of increasing temperature variability in European summer heatwaves. Nature 427, pp. 332 - 336.

Schoeneberger, M. M. (2009). Agroforestry: working trees for sequestering carbon on agricultural lands. Agroforestry Systems, 75(1), pp. 2737.

Schoeneberger, M., Bentrup, G., de Gooijer, H., Soolanayakanahally, R., Sauer, T., Brandle, J., \& Current, D. (2012). Branching out: agroforestry as a climate change mitigation and adaptation tool for agriculture. Journal of Soil and Water Conservation, 67(5), pp. 128A-136A.

Schroth, G. (2004). Agroforestry and biodiversity conservation in tropical landscapes. Island Press. 
Schwab, N., Schickhoff, U., \& Fischer, E. (2015). Transition to agroforestry significantly improves soil quality: A case study in the central midhills of Nepal. Agriculture, Ecosystems \& Environment, 205, pp. 57-69.

Schwendenmann, L., Veldkamp, E., Moser, G., Hölscher, D., Koehler, M., Clough, Y., \& Leitner, D. (2010). Effects of an experimental drought on the functioning of a cacao agroforestry system, Sulawesi, Indonesia. Global Change Biology, 16(5), pp. 1515-1530.

Sierra, J., Dulormne, M., \& Desfontaines, L. (2002). Soil nitrogen as affected by Gliricidia sepiumin a silvopastoral system in Guadeloupe, French Antilles. Agrofor Syst 54, pp. 87-97.

Sileshi, G., Akinnifesi, F. K., Ajayi, O. C., Chakeredza, S., Kaonga, M., \& Matakala, P. W. (2007). Contributions of agroforestry to ecosystem services in the Miombo eco-region of eastern and southern Africa. African journal of environmental science and technology, 1(4), pp. 68-80.

Smith, R. (1929). Tree Crops: A Permanent Agriculture. Island Press, Washington.

Smyth, A. J., \& Dumanski, J. (1993). FESLM: An international framework for evaluating sustainable land management. Rome: FAO, p. 76.

Stamps, W. T., \& Linit, M. J. (1997). Plant diversity and arthropod communities: implications for temperate agroforestry. Agroforestry Systems, 39(1), p. 73.

Stamps, W. T., Woods, T. W., Linit, M. J., \& Garrett, H. E. (2002). Arthropod diversity in alley cropped black walnut (Juglans nigra L.) stands in eastern Missouri, USA. Agroforestry Systems, 56(2), pp. 167-175.

Syampungani, S., Chirwa, P. W., Akinnifesi, F. K., \& Ajayi, O. C. (2010). The potential of using agroforestry as a win-win solution to climate change mitigation and adaptation and meeting food security challenges in Southern Africa. Agricultural Journal, 5(2), pp. 80-88.

UNCCD (2015) United Nations Convention to Combat Desertification. http://www.unccd.int/en/about-the-convention/Pages/ About-the-Convention.aspx ELD Initiative. The value of land: Pros- 
perous lands and positive rewards through sustainable land management. Available online: http://www.eld-initiative.org

UNCCD. (2004).UNCCD Ten Years On. Secretariat of the United Nations Convention to Combat Desertification (UNCCD). Bonn, Germany.

Verchot, L. V., Van Noordwijk, M., Kandji, S., Tomich, T., Ong, C., Albrecht, A., \& Palm, C. (2007). Climate change: linking adaptation and mitigation through agroforestry. Mitigation and adaptation strategies for global change, 12(5), pp. 901-918.

Wheeler, T., \& Von Braun, J. (2013). Climate change impacts on global food security. Science, 341(6145), pp. 508-513.

Williams, P. A., Gordon, A. M., Garrett, H. E., \& Buck, L. (1997). Agroforestry in North America and its role in farming systems.

Zhou, X. H., Brandle, J. R., Awada, T. N., Schoeneberger, M. M., Martin, D. L., Xin, Y., \& Tang, Z. H. (2011). The use of forest-derived specific gravity for the conversion of volume to biomass for open-grown trees on agricultural land. Biomass and Bioenergy 35, pp. 17211731. 
